\title{
Transient Encephalopathy with A Single Dose of Oral Metronidazole: A Case Report
}

\author{
Tek Doz Oral Metronidazol ile Gelişen Geçici Ensefalopati Olgusu: Olgu Sunumu
}

\author{
Erman Altunışık 1 , (1) Şebnem Zeynep Eke Kurt² \\ ${ }^{1}$ Adiyaman University Training and Research Hospital, Clinic of Neurology, Adiyaman, Turkey \\ 2Adiyaman University Training and Research Hospital, Clinic of Emergency Medicine, Adiyaman, Turkey
}

\begin{abstract}

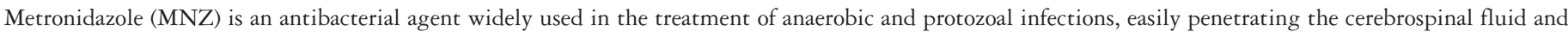

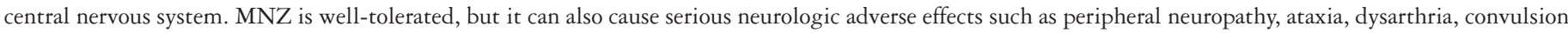

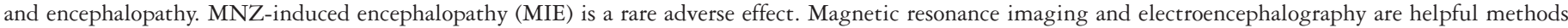

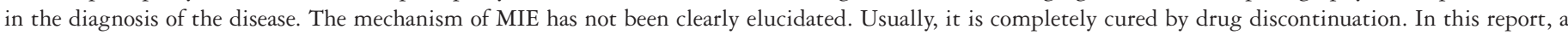
reversible encephalopathy developing in a male patient after receiving a single dose of oral MNZ is presented.
\end{abstract}

Keywords: Metronidazole, encephalopathy, electroencephalography

\section{$\ddot{O} \mathbf{z}$}

Metronidazol (MNZ) anaerobik ve protozoal enfeksiyonların tedavisinde yaygın olarak kullanılan, beyin omurilik sivisı ve santral sinir sistemine kolaylıkla penetre olabilen antibakteriyel ajandır. MNZ oldukça iyi tolere edilir ancak periferal nöropati, ataksi, dizartri, konvülziyon ve ensefalopati gibi ciddi nörolojik yan etkiler de oluşturabilir. MNZ ile indüklenen ensefalopati (MIE) nadir görülen bir yan etkidir. Manyetik rezonans görüntüleme ve elektroensefalografi hastalık tanısında yardımcı yöntemlerdir. MİE’nin mekanizması net aydınlatılabilmiş değildir. Genellikle ilaç kesilmesiyle tamamen düzelme eğilimindedir. Bu yazıda tek doz oral MNZ alan erkek bir hastada gelişen ve hızla düzelen geçici ensefalopati tablosu sunulmuştur.

Anahtar Kelimeler: Metronidazol, ensefalopati, elektroensefalografi

\section{Introduction}

Metronidazole (MNZ) is widely used in the treatment of anaerobic and protozoal infections and is known to easily penetrate the cerebrospinal fluid (CSF) and central nervous system (CNS) (1). The most common adverse effects of MNZ are nausea, headache, and a metallic taste (2). MNZ is fairly well-tolerated, but it can also cause some serious neurologic adverse effects. These neurologic findings are peripheral neuropathy, ataxia, dysarthria, convulsion, and encephalopathy (3). MNZ-induced encephalopathy (MIE) is a rare adverse effect. Its incidence is unknown and generally tends to resolve completely with drug withdrawal (4). The mechanism of MIE has not been clearly elucidated. Some opinions have been put forward on this issue. It is thought that MNZ's intermediate metabolites modulate the inhibitory neurotransmitter GABA receptor, especially in the cerebellar and vestibular systems, and react with catecholamines to form semiquinone and nitro anion neurotoxic radicals (5). The dentate nucleus in the cerebellum is the most frequently affected area on magnetic resonance imaging (MRI). This is followed by the periaquaductal gray matter, dorsal pons, and tectum. The dorsal medulla and corpus callosum are also rarely affected. In addition, vasogenic edema observed in diffusion-weighted imaging (DWI) and apparent diffusion coefficient (ADC) sequences is valuable for diagnosis (6). Some electroencephalographic (EEG) changes may also occur in MIE (7). The purpose of the case report was to draw attention to the fact that this agent, which is used frequently in clinical practice, may affect the CNS, even with a single oral dose.

Address for Correspondence/Yazışma Adresi: Erman Altunışık MD, Adiyaman University Training and Research Hospital, Clinic of Neurology, Adiyaman, Turkey Phone: +90 5054674669 E-mail: ermanaltunisik@gmail.com ORCID: orcid.org/0000-0002-5996-2090

Received/Geliş Tarihi: 18.02.2020 Accepted/Kabul Tarihi: 23.04.2020

${ }^{\circ}$ Copyright 2021 by Turkish Neurological Society

Turkish Journal of Neurology published by Galenos Publishing House. 


\section{Case Report}

A 43-year-old male patient was brought to the emergency room with a change in consciousness. His medical history and family history were unremarkable. There was no history of convulsions. It was learned that he had a history of gastroenteritis for 3 days, and that oral $500 \mathrm{mg} \mathrm{MNZ}$ treatment was started in a different center where he was admitted the day before. When the patient slept and woke up after using a single oral dose of $500 \mathrm{mg}$ MNZ, the clinical picture consisting of inability to communicate with relatives, meaningless speech and behavior, confusion and agitation occurred. There was no history of substance or alcohol use. There was no information in the anamnesis that could indicate malnutrition. There was no fever and other vital parameters were within normal limits. A neurologic examination revealed confusion, agitation, disorientation, and limited cooperation. Pupils were isochoric and light reflex was bilaterally intact. There was no neck stiffness. There was no cranial nerve pathology and fundus examination was normal. All four limbs were equally mobile. Deep tendon reflexes were normoactive. Sensory and cerebellar examinations could not be performed effectively because the patient was noncooperative. The plantar reflex was bilaterally normal. The patient was hospitalized with a pre-diagnosis of encephalopathy. No significant pathology was found in the patient's brain MRI, DWI, and ADC imagings. Lumbar puncture was performed to eliminate CNS infection. CSF protein, sodium, chlorine, glucose, and lactate dehydrogenase levels were normal, no cells were observed in a direct microscopic examination, and no growth was observed in the CSF culture. Liver and kidney function tests were unremarkable. C-reactive protein, procalcitonin, and hemogram were within normal limits. No positive findings were found in a toxin screening of blood and urine. The ethyl alcohol level in the blood and carboxyhemoglobin level in blood gas were normal. No amphetamine, methamphetamine, benzodiazepine, barbiturate, opiate, marijuana, cocaine, methadone or tricyclic antidepressants were detected in urine. Slow-wave activity consisting of generalized paroxysmal theta waves was observed in EEG (Figure 1). MIE was considered in the patient. MNZ was stopped and the patient was hydrated. After 48 hours, a significant improvement was observed in the patient's clinical picture. EEG was checked and found to be completely normal (Figure 2). The patient, whose general

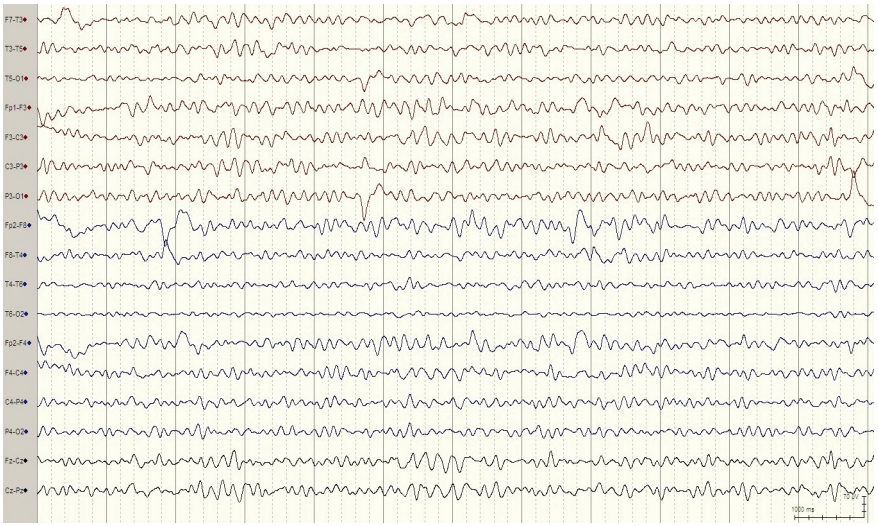

Figure 1. Generalized paroxysmal theta slow-wave activity in EEG performed in the acute phase

EEG: Electroencephalography condition improved and neurologic examination was normal, was discharged. During the 1-year follow-up, no change was observed in the patient's status. The encephalopathy that developed due to a single oral dose of $500 \mathrm{mg} \mathrm{MNZ}$ and rapidly improved was considered worthy of presentation.

\section{Discussion}

Encephalopathy is a rare but known adverse effect of MNZ treatment (2). As in our patient, MIE is mostly reversible and the results are gratifying. However, patients with persistent neurologic symptoms during long-term follow-ups have also been reported (8). Fatal encephalopathy developed in one patient (9).

When the patients presented in the literature were examined, it was observed that MIE occurred especially when an intravenous form of MNZ was used for a long time $(2,9,10)$. In the literature, there are cases of encephalopathy caused by the use of MNZ with cumulative doses of $24 \mathrm{~g}$ and $41.25 \mathrm{~g}$, and it was reported that the use of cumulative doses of MNZ increased the risk of toxicity and worsened the prognosis (11). In addition, publications are reporting that it occurred with the use of MNZ exceeding $2 \mathrm{~g} /$ day dose, especially for long periods (12). On the other hand, there are also publications stating that there was no clear relationship between the daily MNZ dose or the duration of treatment and the onset of neurologic symptoms, and that the onset of the first symptoms might occur between the beginning of the treatment and the $13^{\text {th }}$ week (4). In addition, it was reported in some publications that neurotoxicity was not related to serum concentrations (13). We found no reports of patients with encephalopathy after a single dose of oral MNZ in the literature. In our patient, symptoms occurred in the evening of the same day when the patient received a single oral dose of $500 \mathrm{mg}$ MNZ. This coincides with the idea that the drug or its metabolites do not need to reach a certain serum concentration to cause MIE.

The primary treatment method of MIE is drug discontinuation. It was observed that even abnormal MRI findings resolved within 3-16 weeks and clinical improvement accompanied this in many patients (8). In our patient, 48 hours after the cessation of treatment, the patient's clinical picture recovered rapidly and completely. Some MRI findings have been described for MIE. It was reported that the underlying mechanism was axonal swelling and increased water content rather than demyelination, and the

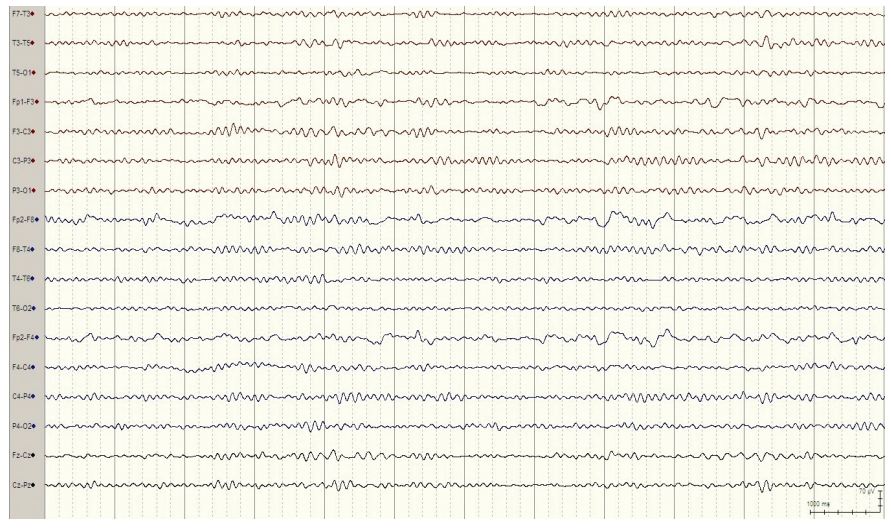

Figure 2. Normal EEG activity in alpha rhythm recorded 48 hours after treatment cessation

EEG: Electroencephalography 
most frequently affected areas were the cerebellar dentate nucleus and inferior colliculus (14). In some patients, no MRI findings were found (15). In our patient, we found no positive findings in either conventional MRI or DWI and ADC sequences.

There may also be some EEG changes in MIE. Changes that occur, especially in the early stage, can make EEG a helpful tool in the diagnosis of MIE. Diffuse slowing consisting of theta and delta waves was observed in some reported patients (12), and patients with generalized triphasic periodic discharges (7) or non-convulsive status epilepticus EEG pattern were also reported (10). EEG patterns are not related to the dose used and have no predictive value for prognosis. In addition, an electrophysiologic improvement was accompanied by clinical improvement following drug discontinuation in most patients (7). In our patient, generalized paroxysmal theta waves were observed in the early EEG examination. An EEG examination performed 48 hours after drug withdrawal and hydration was found to be completely normal, in parallel with clinical improvement.

MNZ is a frequently used agent in clinical practice. Although it is well-tolerated, it can rarely cause serious neurologic adverse effects. In MRI examinations, pathologic structural findings may not be detected in all patients, and if possible, all patients should undergo EEG. We think that the development of MIE is not dosedependent, it should be kept in mind that this picture may occur even with a single dose.

\section{Ethic}

Informed Consent: Informed consent form was obtained from the patient presented in our study.

Peer-review: Externally and internally peer-reviewed.

\section{Authorship Contributions}

Surgical and Medical Practices: Ş.Z.E.K., Concept: E.A., Design: E.A., Data Collection or Processing: Ş.Z.E.K., Analysis or Interpretation: E.A., Literature Search: E.A., Writing: E.A.

Conflict of Interest: No conflict of interest was declared by the authors.
Financial Disclosure: The authors declared that this study received no financial support.

\section{References}

1. Freeman CD, Klutman NE, Lamp KC. Metronidazole. A therapeutic reviewand update. Drugs 1997;54:679-678.

2. Hammamia N, Drissia C, Sebaia R, et al. Reversible metronidazole-induced encephalopathy. J Neuroradiol 2007;34:133-136.

3. Finegold SM. Metronidazole. Ann Intern Med 1980;93:585-587.

4. Omotoso AB, Opadijo OG. Acute encephalopathy associated with metronidazole therapy. Afr J Med Med Sci 1997;26:97-98.

5. Bradley WG, Karlsson IJ, Rassol CG. Metronidazole neuropathy. Br Med J 1977;2:610-611.

6. Kim E, Na DG, Kim EY, et al. Imaging of metronidazole induced encephalopathy: Lesion distribution and diffusion-weighted imaging findings. AJNR Am J Neuroradiol 2007;28:1652-1658.

7. Wang HH, Kwan SY. Electroencephalographic periodic discharges in metronidazoleinduced encephalopathy: A case report. Acta Neurol Taiwan 2017;26:184-188.

8. Kim DS, Jung JW, Kim JY, et al. Reversible MRI findings in metronidazoleinduced cerebellar dysfunction. J Korean Neurol Assoc 1999;17:904-907.

9. Groothoff MV, Hofmeijer J, Sikma MA, Meulenbelt J. Irreversible encephalopathy after treatment with high-dosentravenous metronidazole. Clin Ther 2010;32:60-64.

10. Cantador A, Meschia JF, Freeman WD, Tatum WO. Nonconvulsive status with metronidazole. Neurohospitalist 2013;3:185-189.

11. Huang YT, Chen LA, Cheng SJ. Metronidazole-induced encephalopathy: Case report and review literature. Acta Neurol Taiwan 2012;21:74-78.

12. Önder H. A Case of MRI negative metronidazole-1nduced encephalopathy and recovery of electroencephalography at follow-up. J Neurol Res 2016;6:81-84.

13. Halloran TJ. Convulsions associated with high cumulative doses of metronidazole. Drug Intell Clin Pharm 1982;16:409.

14. Ahmed A, Loes DJ, Bressler EL. Reversible magnetic resonance imaging findings in metronidazole-induced encephalopathy. Neurology $1995 ; 45: 588-589$.

15. Arik N, Cengiz N, Bilge A. Metronidazole-induced encephalopathy in a uremic patient: a case report. Nephron 2001;89:108-109. 